Crystal structure of ( $\mathrm{Li} 0.5 \mathrm{~K} 0.5) 2 \mathrm{CO} 3$ by neutron powder diffraction analysis*

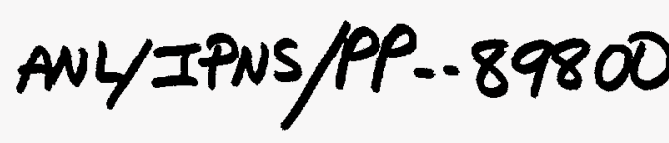

Yasushi Idemoto, a,b James W. Richardson, Jr., a Nobuyuki Koura, b

Shinji Kohara, ${ }^{b}$ and C.-K. Loong ${ }^{a}$

a Intense Pulsed Neutron Source, Argonne National Laboratory, Argonne, Illinois 604394814 , U. S. A.

b Department of Industrial Chemistry, Faculty of Science and Technology, Science University of Tokyo, 2641 Yamazaki, Noda-shi, Chiba 278, Japan

The submitted manuscript has been authored by a contractor of the U.S. Government under contract No. W-31-109-ENG38. Accordingly, the U. S. Government retains a nonexclusive, royalty-free license to publish or reproduce the published form of this contribution, or allow others to do so, for U. S. Government purposes.

Submitted to Journal of The Electrochemical Society

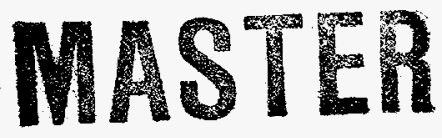

*Work supported by U. S. Department of Energy, BES, contract No. W-31-109-ENG-38 


\section{DISCLAMIER}

Portions of this document may be illegible in electronic image products. Images are produced from the best available original docoment. 


\title{
Crystal structure of $\left(\mathrm{Li}_{0.5} \mathrm{~K}_{0.5}\right)_{2} \mathrm{CO}_{3}$ by neutron powder diffraction analysis
}

\author{
Yasushi Idemoto, a,b James W. Richardson, Jr., a Nobuyuki Koura, ${ }^{b}$ \\ Shinji Kohara, ${ }^{b}$ and C.-K. Loong ${ }^{a}$
}

a Intense Pulsed Neutron Source, Argonne National Laboratory, Argonne, Illinois 60439-4814, U.S.A.

b Department of Industrial Chemistry, Faculty of Science and Technology, Science University of Tokyo, 2641 Yamazaki, Noda-shi, Chiba 278, Japan

\begin{abstract}
The crystal structure of $\left(\mathrm{Li}_{0.5} \mathrm{~K}_{0.5}\right)_{2} \mathrm{CO}_{3}$ was determined by neutron powder diffraction. A final weighted $\mathrm{R}$-factor of $4.54 \%$ was obtained for the refinement of 2373 reflections by the Rietveld method from a sample synthesized using ${ }^{7} \mathrm{Li}_{2} \mathrm{CO}_{3}$ and $\mathrm{K}_{2} \mathrm{CO}_{3}$ (99.9\% pure). Slight distortion of the $\mathrm{CO}_{3}{ }^{2-}$ units in the monoclinic cell was observed; the $\mathrm{O}(1)-\mathrm{C}-\mathrm{O}(2)$ angle and $\mathrm{C}$ $\mathrm{O}(3)$ length are larger than those for the other $\mathrm{C}-\mathrm{O}$ bonds and $\mathrm{O}-\mathrm{C}-\mathrm{O}$ angles. These localstructure characteristics can be explained by the difference in the ionic size of $\mathrm{Li}^{+}$and $\mathrm{K}^{+}$, and the different electrostatic interactions between the cations and $\mathrm{CO}_{3}{ }^{2-}$ units.
\end{abstract}




\section{Introduction}

The promising efficiency and attractive environmental features of molten carbonate fuel cells have attracted keen attention from electrochemists in recent years. In particular, concerns such as corrosion of electrodes and reduction processes of oxygen in mixed $\mathrm{Li}_{2} \mathrm{CO}_{3}-\mathrm{K}_{2} \mathrm{CO}_{3}$ molten salts have been the subject of intense studies. Both issues involve electroactive $\mathrm{CO}_{3}{ }^{2-}$ species, their interaction with cations of the electrodes and inter-diffusion with $\mathrm{O}_{2}$ and $\mathrm{CO}_{2}$. These properties are closely related to the structural differences of the materials near and in between the eutectic compositions. Information regarding the configuration of $\mathrm{CO}_{3}{ }^{2-}$ with respect to the alkali ions in molten and solid-state solution of $\mathrm{Li}_{2} \mathrm{CO}_{3}-\mathrm{K}_{2} \mathrm{CO}_{3}$ is not complete. Recent molecular-dynamics (MD) simulations of molten $\left(\mathrm{Li}_{0.5} \mathrm{~K}_{0.5}\right)_{2} \mathrm{CO}_{3}$ indicated that a $\mathrm{Li}^{+}$ion is located near one $\mathrm{O}$ atom of a $\mathrm{CO}_{3}{ }^{2-}$ ion, and a $\mathrm{K}^{+}$ion is at an intermediate position between two $\mathrm{O}$ atoms of the $\mathrm{CO}_{3}{ }^{2-}$ ion. ${ }^{1-3}$ Furthermore, simulations suggested that cation sites surrounding $\mathrm{CO}_{3}{ }^{2-}$ ions change with the $\mathrm{Li} / \mathrm{K}$ ratio. ${ }^{2}$ However, $\mathrm{MD}$ simulations ${ }^{1-3}$ and $a b$ initio calculations ${ }^{4}$ do not determine precisely the near-neighbor distances and angles, nor do they identify geometric changes in $\mathrm{CO}_{3}{ }^{2-}$ unit responding to preferential coordination of $\mathrm{Li}^{+}$and $\mathrm{K}^{+}$ions. Detailed crystal structure determinations can provide these insights. In particular, structural changes resulting from changes in $\mathrm{Li} / \mathrm{K}$ ratio may be correlated with variations of thermodynamic properties and performance of the fuel cells. This letter reports the crystal structure of a $\left(\mathrm{Li}_{0.5} \mathrm{~K}_{0.5}\right)_{2} \mathrm{CO}_{3}$ powder by neutron-diffraction measurements.

Several authors have reported the solid-liquid phase diagram for mixtures of $\mathrm{Li}_{2} \mathrm{CO}_{3}$ and $\mathrm{K}_{2} \mathrm{CO}_{3} \cdot 5,6$ These data suggest that a solid solution with composition $\mathrm{Li}_{2} \mathrm{CO}_{3}: \mathrm{K}_{2} \mathrm{CO}_{3}=0.5: 0.5$ may form a single-phase material at room temperature. The crystal structure of $\left(\mathrm{Li}_{0.5} \mathrm{~K}_{0.5}\right)_{2} \mathrm{CO}_{3}$ has been studied by $\mathrm{x}$-ray diffraction ${ }^{7}$ and the lattice parameters and space group were reported. However, a detailed crystal structure determination was not achieved. To the best of our knowledge, no neutron-diffraction studies of $\mathrm{Li}_{2} \mathrm{CO}_{3}-\mathrm{K}_{2} \mathrm{CO}_{3}$ have been reported so far. This may be in part due to difficulties encountered when analyzing neutron-diffraction data from samples containing natural $\mathrm{Li}\left({ }^{6} \mathrm{Li} 7.42 \%+{ }^{7} \mathrm{Li} 92.58 \%\right)$, since the neutron absorption coefficient 
of ${ }^{6} \mathrm{Li}$ is large. The samples used in this study were prepared by mixing ${ }^{7} \mathrm{Li}_{2} \mathrm{CO}_{3}$ with $\mathrm{K}_{2} \mathrm{CO}_{3}$ to avoid this problem.

\section{Experimental Details}

$\mathrm{Li}_{2} \mathrm{CO}_{3}$ powder of $99.9 \%$ purity and $99.9 \%{ }^{7} \mathrm{Li}$ isotopic substitution, supplied by Tomiyama's High Purity Chemicals, and $\mathrm{K}_{2} \mathrm{CO}_{3}$ powder of $99.9 \%$ purity, supplied by Wako Pure Chemical Ind. Ltd., were used as starting materials. The carbonates were dried at $450^{\circ} \mathrm{C}$ for $12 \mathrm{~h}$ in air. $\mathrm{Li}_{2} \mathrm{CO}_{3}$ and $\mathrm{K}_{2} \mathrm{CO}_{3}$ were then mixed in a 1:1 molar ratio, and placed in an alumina crucible for melting. The sample was first heated at a rate of $30^{\circ} \mathrm{C} / \mathrm{min}$ to $650^{\circ} \mathrm{C}$ and kept for $1 \mathrm{~h}$ in air. The melt was then quenched to room temperature by pouring it on a copper plate in air. The quenched sample was placed in a dry box under flowing dry nitrogen gas, and ground into a powder. The resulting sample was dried at $450^{\circ} \mathrm{C}$ for $1.5 \mathrm{~h}$ in air. This process was repeated one time.

Time-of-flight (TOF) neutron powder diffraction was performed using the General Purpose Powder Diffractometer (GPPD) at Argonne's Intense Pulsed Neutron Source (IPNS). ${ }^{8}$ A powder sample was enclosed in a thin-wall vanadium can $(11 \mathrm{~mm}$ diameter, $50 \mathrm{~mm}$ long). Independent TOF data were recorded on eight detector banks positioned at scattering angles ranging from $\pm 15^{\circ}$ to $\pm 150^{\circ}$. The back-scattering geometry (at a mean scattering angle of $\pm 148^{\circ}$ ) corresponds to the highest resolution ( $\Delta d / d=0.25 \%$ where $d$ is the atomic spacing). For the measurement of $\left({ }^{7} \mathrm{Li}_{0.5} \mathrm{~K}_{0.5}\right)_{2} \mathrm{CO}_{3}$, a $3.3 \mathrm{~g}$ of powder was used, and data were collected for $9 \mathrm{~h}$ at room temperature. The crystal structure was refined with the Rietveld technique (GSAS program ${ }^{9}$ ).

\section{Results and Discussion}

The intensity profile of the $\left({ }^{7} \mathrm{Li}_{0.5} \mathrm{~K}_{0.5}\right)_{2} \mathrm{CO}_{3}$ sample was analyzed over a large d-spacing range from 0.5 to $2.9 \AA$, which consisted of 4910 data points and 2373 reflections. An initial refinement was carried out by assuming a monoclinic unit cell isostructural with $\mathrm{K}_{2} \mathrm{CO}_{3}{ }^{7}$ Subsequent analyses concluded a single-phase structure for $\left(\mathrm{Li}_{0.5} \mathrm{~K}_{0.5}\right)_{2} \mathrm{CO}_{3}$ of monoclinic symmetry (space group $\mathrm{P} 2{ }_{\mathrm{l}} / \mathrm{c}$ ). The final refined parameters are listed in Tables 1 and 2 , and the 
unit cell is shown in Fig. 1. Fig. 2 illustrates the resulted profile fit where good agreement between the observed and calculated patterns and a low $\mathrm{R}$-factor $\left(\mathrm{R}_{\mathrm{wp}}=4.54 \%\right)$ were obtained. The lattice parameters agree reasonably well with those obtained by Christmann and coworkers ${ }^{7}$ previously from $\mathrm{x}$-ray diffraction. As shown in Table 2, our results show that $\mathrm{Li}^{+}$and $\mathrm{K}^{+}$ions occupy different sites and that all cation sites are fully occupied, in good agreement with previous MD simulations. ${ }^{1}$

Selected bond lengths and angles from structural parameters are listed in Table 3. In contrast with the carbonate groups in isostructural $\mathrm{K}_{2} \mathrm{CO}_{3},{ }^{10}$ the $\mathrm{CO}_{3}$ units in $\left(\mathrm{Li}_{0.5} \mathrm{~K}_{0.5}\right)_{2} \mathrm{CO}_{3}$ are slightly distorted. The $\mathrm{O}(1)-\mathrm{C}-\mathrm{O}(2)$ bond angle of $123.2 \pm 0.2^{\circ}$ is somewhat larger than that $\left(118.4 \pm 0.3^{\circ}\right)$ of $\mathrm{O}(2)-\mathrm{C}-\mathrm{O}(3)$ and $\mathrm{O}(3)-\mathrm{C}-\mathrm{O}(1)$. In addition, a longer bond length of $\mathrm{C}-\mathrm{O}(3)$ $(1.301 \AA)$ compared to those of $\mathrm{C}-\mathrm{O}(1)$ and $\mathrm{C}-\mathrm{O}(2)(1.281$ and $1.271 \AA$, respectively) was clearly identified. A selected portion of the crystal structure is shown in Fig. 3 to illustrate this situation. The 7 atoms shown are located roughly in the plane of the figure. The observed differences in bond distances and angles within the $\mathrm{CO}_{3}$ unit can be understood by comparing with $\mathrm{K}_{2} \mathrm{CO}_{3}$ where $\mathrm{Li}$ sites would be occupied by $\mathrm{K}$ atoms. While this group of atoms in $\mathrm{K}_{2} \mathrm{CO}_{3}$ closely follows a $\mathrm{D}_{3 \mathrm{~h}}$ point symmetry around carbon, in $\left(\mathrm{Li}_{0.5} \mathrm{~K}_{0.5}\right)_{2} \mathrm{CO}_{3}$ the local symmetry is closer to $\mathrm{C}_{2 v}$. Furthermore, each $\mathrm{Li}^{+}$ion is 4 -fold coordinated whereas $\mathrm{K}^{+}$exhibits 7 -fold coordination. Because $\mathrm{Li}^{+}$is considerably smaller than $\mathrm{K}^{+}$, these differences in local symmetry and coordination will strongly influence the bond lengths and angles. Local structural variations in $\left(\mathrm{Li}_{\mathrm{x}} \mathrm{K}_{1-\mathrm{x}}\right)_{2} \mathrm{CO}_{3}$ materials can, therefore, be explained by the difference in ionic size between $\mathrm{Li}^{+}$ and $\mathrm{K}^{+}$and the consequent differences in electrostatic interactions.

A separate sample of $\left(\mathrm{Li}_{0.5} \mathrm{~K}_{0.5}\right)_{2} \mathrm{CO}_{3}$ was prepared, in the same manner as the first sample, using natural $\mathrm{Li}_{2} \mathrm{CO}_{3}$. As expected, a Rietveld refinement of the diffraction data from this sample resulted in a larger $\mathrm{R}_{\mathrm{wp}}(5.28 \%)$ than that obtained with the ${ }^{7} \mathrm{Li}$ enriched sample (4.54\%). The improvement from ${ }^{7} \mathrm{Li}$ enrichment is due to the lower absorption coefficient of ${ }^{7} \mathrm{Li}$ than ${ }^{6} \mathrm{Li}$. Complete details of neutron-diffraction results for both the isotopic and natural $\mathrm{Li}_{2} \mathrm{CO}_{3}, \mathrm{~K}_{2} \mathrm{CO}_{3}$, $\left(\mathrm{Li}_{0.43} \mathrm{~K}_{0.57}\right)_{2} \mathrm{CO}_{3}$, and $\left(\mathrm{Li} 0.62 \mathrm{~K}_{0.38}\right)_{2} \mathrm{CO}_{3}$ samples will be reported in a separate paper. 


\section{Conclusion}

The crystal structure of $\left(\mathrm{Li}_{0.5} \mathrm{~K}_{0.5}\right)_{2} \mathrm{CO}_{3}$ has been determined by TOF neutron powder diffraction. Asymmetry in the $\mathrm{CO}_{3}{ }^{2-}$ units in terms of larger $\mathrm{O}(1)-\mathrm{C}-\mathrm{O}(2)$ bond angle and $\mathrm{C}$ $\mathrm{O}(3)$ bond length than the other corresponding angles and lengths in the $\mathrm{CO}_{3}{ }^{2-}$ unit was observed. Differences in bond angles and bond lengths are influenced by electrostatic interactions between the $\mathrm{CO}_{3}{ }^{2-}$ units and the $\mathrm{Li}^{+}$ion and $\mathrm{K}^{+}$ions. The improved refinements $R_{w p}$ from $5.28 \%$ to $4.54 \%$ - by using isotopically enriched samples, prepared by using ${ }^{7} \mathrm{Li}_{2} \mathrm{CO}_{3}$ instead of the natural compound, demonstrates that ${ }^{7} \mathrm{Li}$ isotopic substitution is effective for the determination of an accurate crystal structure by neutron diffraction.

\section{Acknowledgments}

The authors wish to acknowledge the valuable assistance of Ray Thomas (Argonne) in the neutron-diffraction experiments. This work has benefited from the use of the Intense Pulsed Neutron Source at Argonne National Laboratory. This facility is funded by the U.S. Department of Energy, BES-Materials Science, under CONTRACT W-31-109-ENG-38.

\section{DISCLAIMER}

\footnotetext{
This report was prepared as an account of work sponsored by an agency of the United States Government. Neither the United States Government nor any agency thereof, nor any of their employees, makes any warranty, express or implied, or assumes any legal liability or responsibility for the accuracy, completeness, or usefulness of any information, apparatus, product, or process disclosed, or represents that its use would not infringe privately owned rights. Reference herein to any specific commercial product, process, or service by trade name, trademark, manufacturer, or otherwise does not necessarily constitute or imply its endorsement, recommendation, or favoring by the United States Government or any agency thereof. The views and opinions of authors expressed herein do not necessarily state or reflect those of the United States Government or any agency thereof.
} 


\section{References}

1. N. Fujimoto and N. Koura, Denki Kagaku, 57, 910 (1989).

2. N. Fujimoto and N. Koura, Denki Kagaku, 59, 594 (1991).

3. J. T. W. M. Tissen, G. J. M. Janssen and J. P. van der Eerden, Mol. Phys., 82, 101 (1994).

4. N. Koura, S. Kohara, K. Takeuchi, S. Takahashi, M.-L. Saboungi, L. A.Curtiss and M. Grimsditch,. J. Mol. Structure, in press.

5. G. J. Janz and M. Lorenz, J. Chem.Eng. Data, 6, 321 (1961).

6. K. Babcock and J. Winnic, J. Chem.Eng. Data, 33, 96 (1988).

7. M. Christmann, N. Sandeghi and G. Papin, Rev. Chim. Miner., 15, 312 (1978).

8. J. D. Jorgensen, J. Faber Jr., J. M. Carpenter, R. K. Crawford, J. R. Haumann, R. L. Hitterman, R. Kleb, G. E. Ostrowski, F. J. Rotella and T. G. Worlton, J. Appl. Cryst. 22, 321 (1989).

9. A. C. Larson and R. B. von Dreele, Los Alamos National Laboratory Report, No. LA-UR 86-748, (1987).

10. B. M. Gatehouse and D. J. Lloyd, J. Chem. Soc., Dalton, 70 (1973). 


\section{Figure Captions}

Figure 1. The crystal structure (space group $\left.\mathrm{P} 2{ }_{1} / \mathrm{c}\right)$ of $\left(\mathrm{Li}_{0.5} \mathrm{~K}_{0.5}\right)_{2} \mathrm{CO}_{3}$. The unit cell is shown by the parallelepiped.

Figure 2. Neutron powder diffraction data and Rietveld refinement profile fit for monoclinic $\left(\mathrm{Li}_{0.5} \mathrm{~K}_{0.5}\right)_{2} \mathrm{CO}_{3}$. The symbols (+) represent the background-subtracted data. The solid line is the calculated profile. Tick marks below the profile mark the positions of allowed Bragg reflections. The differences between the observed and calculated intensities are shown at the bottom.

Figure 3. A selected portion of crystal structure for $\left(\mathrm{Li}_{0.5} \mathrm{~K}_{0.5}\right)_{2} \mathrm{CO}_{3}$, illustrating the coordination of $\mathrm{Li}^{+}$and $\mathrm{K}^{+}$ions with the $\mathrm{CO}_{3}{ }^{2-}$ units. Atoms are labeled according to the scheme given in Table 3. 
Table 1 The lattice parameters and cell volume for $\left(\mathrm{Li}_{0.5} \mathrm{~K}_{0.5}\right)_{2} \mathrm{CO}_{3}$ at room temperature.

Numbers within parentheses are statistical standard deviations of the last significant digit.

\begin{tabular}{lcc}
\hline \hline & Neutron & x-ray \\
\hline $\mathrm{a}(\AA)$ & $7.22284(7)$ & $7.232(5)$ \\
$\mathrm{b}(\AA)$ & $7.07673(8)$ & $7.080(4)$ \\
$\mathrm{c}(\AA)$ & $7.59397(9)$ & $7.619(5)$ \\
$\beta$ & $127.421(1)$ & $127.5(1)$ \\
$\mathrm{V}\left(\AA^{3}\right)$ & $308.272(3)$ & \\
\hline
\end{tabular}


Table 2 The crystal structural parameters for $\left(\mathrm{Li}_{0.5} \mathrm{~K}_{0.5}\right)_{2} \mathrm{CO}_{3}$ at room temperature. Rietveld refinements were based on a monoclinic structure (space group $\mathrm{P} 2{ }_{1} / \mathrm{c}$ ), see Table 1 . The occupation factors of all atoms were fixed to unity. The weighted R-factors was $4.54 \%$.

\begin{tabular}{lcccccccccc}
\hline Atom & Site & $\mathrm{x}$ & $\mathrm{y}$ & $\mathrm{z}$ & $\mathrm{U}_{11}\left(\AA^{2}\right)$ & $\mathrm{U}_{22}\left(\AA^{2}\right)$ & $\mathrm{U}_{33}\left(\AA^{2}\right)$ & $\mathrm{U}_{12}\left(\AA^{2}\right)$ & $\mathrm{U}_{13}\left(\AA^{2}\right)$ & $\mathrm{U}_{23}\left(\AA^{2}\right)$ \\
\hline $\mathrm{Li}$ & $4 \mathrm{e}$ & $0.4004(9)$ & $0.0676(8)$ & $0.1019(9)$ & $0.0234(28)$ & $0.0355(32)$ & $0.0383(34)$ & $0.0068(22)$ & $0.0275(28)$ & $0.0025(25)$ \\
$\mathrm{K}$ & $4 \mathrm{e}$ & $-0.1716(5)$ & $0.3553(4)$ & $0.1685(5)$ & $0.0224(17)$ & $0.0220(18)$ & $0.0447(23)$ & $-0.0011(11)$ & $0.0234(17)$ & $0.0023(13)$ \\
$\mathrm{C}$ & $4 \mathrm{e}$ & $0.2939(3)$ & $0.3326(2)$ & $0.2132(3)$ & $0.0206(8)$ & $0.0189(8)$ & $0.0254(10)$ & $-0.0023(8)$ & $0.0165(8)$ & $-0.0039(8)$ \\
$\mathrm{O}(1)$ & $4 \mathrm{e}$ & $0.7436(3)$ & $-0.0243(2)$ & $0.2092(3)$ & $0.0296(11)$ & $0.0193(11)$ & $0.0310(12)$ & $0.0030(8)$ & $0.0240(10)$ & $0.0075(9)$ \\
$\mathrm{O}(2)$ & $4 \mathrm{e}$ & $0.1596(3)$ & $0.1899(3)$ & $0.1294(3)$ & $0.0301(11)$ & $0.0168(10)$ & $0.0421(14)$ & $-0.0032(9)$ & $0.0277(11)$ & $-0.0026(9)$ \\
$\mathrm{O}(3)$ & $4 \mathrm{e}$ & $0.4787(3)$ & $0.3328(3)$ & $0.2207(4)$ & $0.0285(11)$ & $0.0287(10)$ & $0.0552(15)$ & $-0.0094(10)$ & $0.0346(11)$ & $-0.0153(11)$ \\
\hline
\end{tabular}


Table 3 Selected bond lengths (in $\AA$ ) and bond angles (in deg.) for $\left(\mathrm{Li}_{0.5} \mathrm{~K}_{0.5}\right)_{2} \mathrm{CO}_{3}$.

\begin{tabular}{lllr}
\hline $\mathrm{C}_{1}-\mathrm{O}(1)_{5}$ & $1.281(2)$ & $\mathrm{O}(1)_{5}-\mathrm{C}_{1}-\mathrm{O}(2)_{1}$ & $123.2(2)$ \\
$\mathrm{C}_{1}-\mathrm{O}(2)_{1}$ & $1.271(2)$ & $\mathrm{O}(2)_{1}-\mathrm{C}_{1}-\mathrm{O}(3)_{1}$ & $118.3(2)$ \\
$\mathrm{C}_{1}-\mathrm{O}(3)_{1}$ & $1.301(2)$ & $\mathrm{O}(3)_{1}-\mathrm{C}_{1}-\mathrm{O}(1)_{5}$ & $118.5(2)$ \\
$\mathrm{Li}_{1}-\mathrm{O}(1)_{4}$ & $1.942(6)$ & & \\
$\mathrm{Li}_{1}-\mathrm{O}(2)_{1}$ & $2.065(5)$ & & \\
$\mathrm{Li}_{1}-\mathrm{O}(3)_{6}$ & $1.977(6$ & $\mathrm{Li}_{1}-\mathrm{C}_{1}-\mathrm{O}(1)_{5}$ & $174.5(2)$ \\
$\mathrm{K}_{1}-\mathrm{O}(1)_{5}$ & $2.767(3)$ & $\mathrm{Li}_{1}-\mathrm{C}_{1}-\mathrm{O}(2)_{1}$ & $60.5(2)$ \\
$\mathrm{K}_{1}-\mathrm{O}(2)_{2}$ & $2.794(4)$ & $\mathrm{Li}_{1}-\mathrm{C}_{1}-\mathrm{O}(3)_{1}$ & $58.0(2)$ \\
$\mathrm{K}_{1}-\mathrm{O}(3)_{7}$ & $2.789(3)$ & $\mathrm{Li}_{5}-\mathrm{C}_{1}-\mathrm{O}(2)_{1}$ & $170.8(2)$ \\
$\mathrm{C}_{1}-\mathrm{Li}_{1}$ & $2.370(5)$ & & \\
$\mathrm{C}_{1}-\mathrm{Li}_{5}$ & $2.417(5)$ & $\mathrm{K}_{1}-\mathrm{C}_{1}-\mathrm{O}(1)_{5}$ & $60.2(1)$ \\
$\mathrm{C}_{1}-\mathrm{K}_{1}$ & $3.172(3)$ & $\mathrm{K}_{1}-\mathrm{C}_{1}-\mathrm{O}(2)_{1}$ & $63.2(1)$ \\
$\mathrm{Li}_{1}-\mathrm{K}_{3}$ & $3.396(6)$ & $\mathrm{K}_{1}-\mathrm{C}_{1}-\mathrm{O}(3)_{1}$ & $175.9(2)$ \\
$\mathrm{Li}_{1}-\mathrm{Li}_{4}$ & $2.843(1)$ & & \\
$\mathrm{K}_{1}-\mathrm{K}_{3}$ & $4.058(3)$ & $\mathrm{Li}_{1}-\mathrm{C}_{1}-\mathrm{K}_{1}$ & $123.7(2)$ \\
\hline
\end{tabular}

aSubscripts indicate the following equivalent positions.

$\begin{array}{cccc}1 & x & y & z \\ 2 & -x & y+(1 / 2) & -z+(1 / 2) \\ 3 & -x & y-(1 / 2) & -z+(1 / 2) \\ 4 & -x+1 & -y & -z \\ 5 & -x+1 & y+(1 / 2) & -z+(1 / 2) \\ 6 & -x+1 & y-(1 / 2) & -z+(1 / 2) \\ 7 & x-1 & y & z\end{array}$




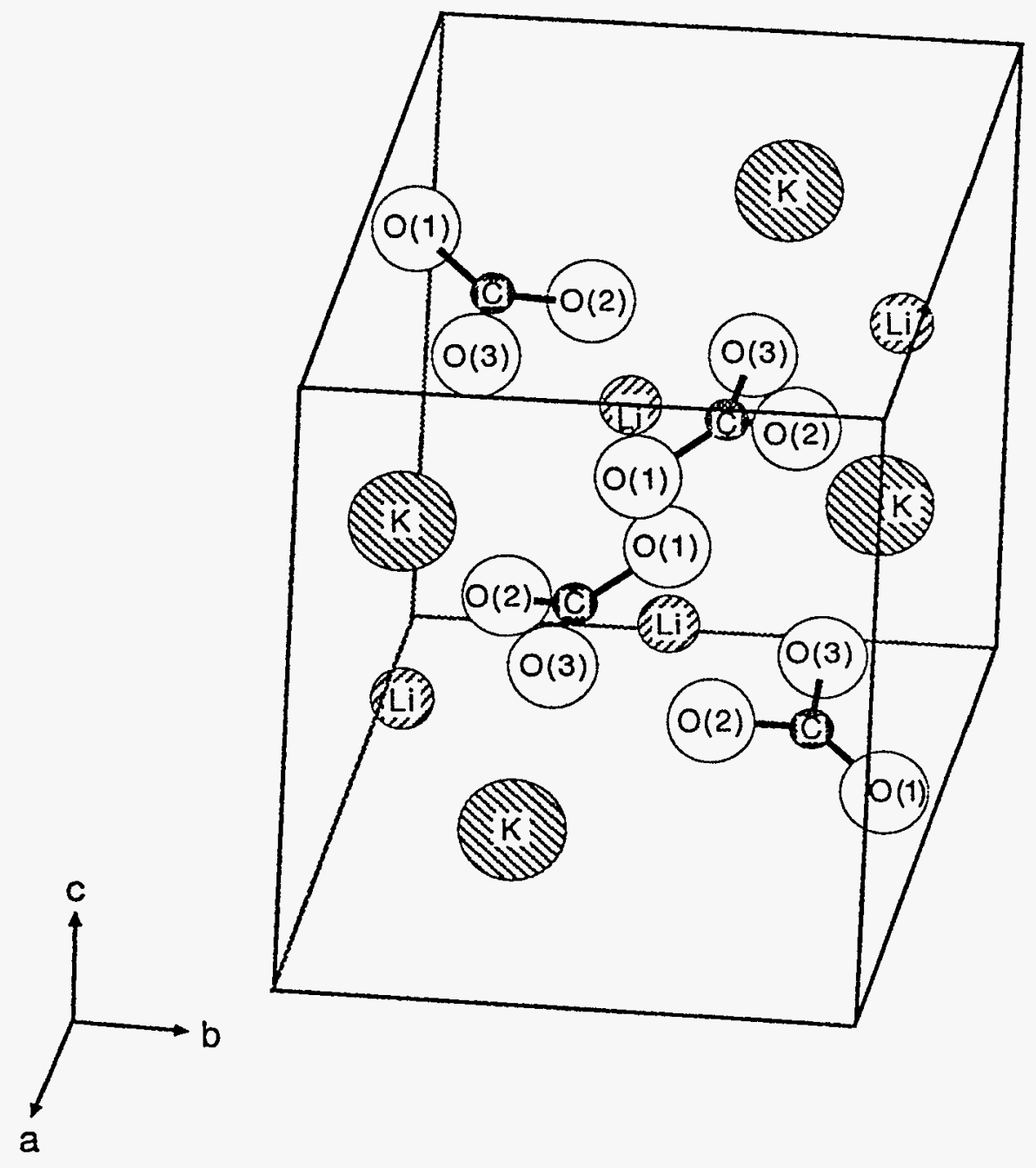


$F i g .2$

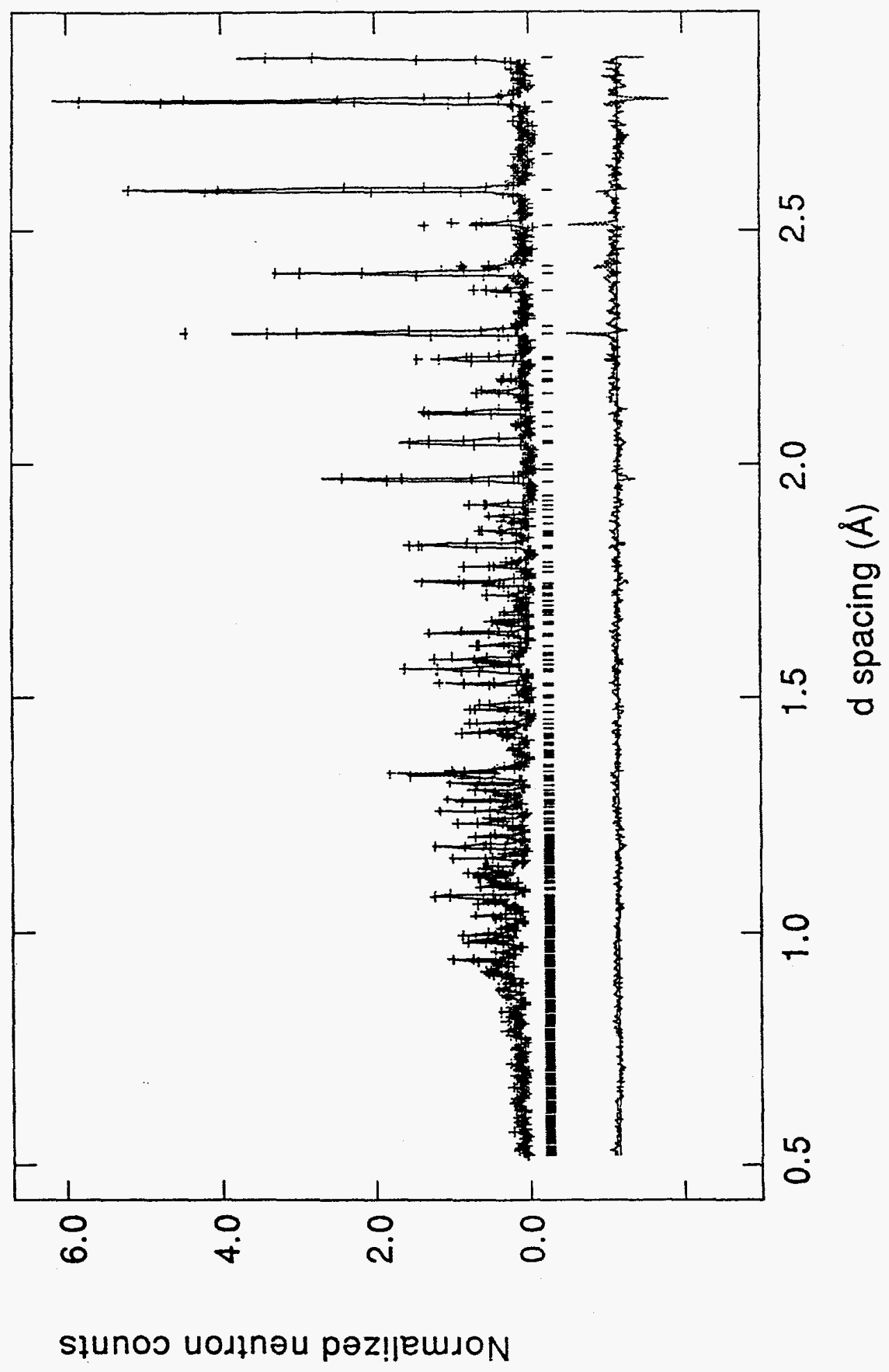


Fis. 3

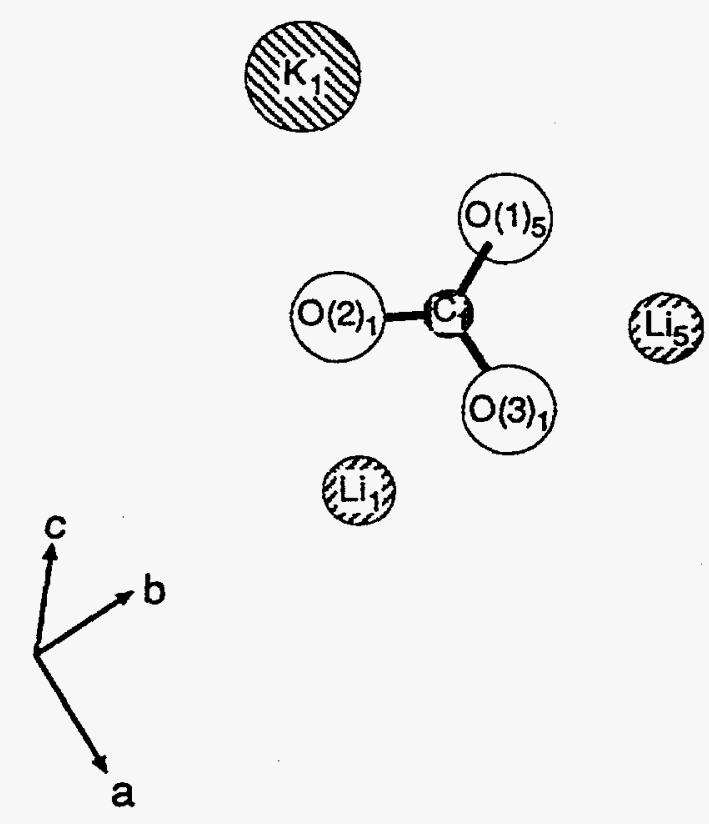

